\title{
Isolated Light Chain of Tetanus Toxin Inhibits Exocytosis: Studies in Digitonin-Permeabilized Cells
}

\author{
Mary A. Bittner, *William H. Habig, and Ronald W. Holz \\ Department of Pharmacology, University of Michigan Medical School, Ann Arbor, Michigan; and ${ }^{*}$ Laboratory of Bacterial \\ Toxins, Division of Bacterial Products, U.S. Food and Drug Administration, Bethesda, Maryland, U.S.A.
}

\begin{abstract}
Previous work indicates that the heavy chain of tetanus toxin is responsible for the binding of the toxin to the neuronal membrane and its subsequent internalization. In the present study, the light chain of tetanus toxin mimicked the holotoxin in inhibiting $\mathrm{Ca}^{2+}$-dependent secretion of $\left[{ }^{3} \mathrm{H}\right]$ norepinephrine from digitonin-permeabilized adrenal chromaffin cells. Preincubation of tetanus toxin with monoclonal antibodies to the light chain prevented the inhibition by tetanus toxin. Preincubation of tetanus toxin with nonimmune ascites fluid or with monoclonal antibodies directed
\end{abstract}

against the $C$ fragment (the $C$-terminal of the heavy chain) or the heavy-chain portion of the B fragment did not prevent inhibition by tetanus toxin. The data indicate that the light chain is responsible for the intracellular blockade of exocytosis. Key Words: Tetanus toxin-Chromaffin cell-Catecholamine-Exocytosis-Digitonin permeabilization. Bittner M. A. et al. Isolated light chain of tetanus toxin inhibits exocytosis: Studies in digitonin-permeabilized cells. $J$. Neurochem. 53, 966-968 (1989).
Tetanus toxin is a 150 -kilodalton $(\mathrm{kDa})$ dichain protein that consists of a heavy chain $(\sim 100 \mathrm{kDa})$ and a light chain $(\sim 50 \mathrm{kDa})$ held together by a disulfide bond (Fig. 1A). The toxin undergoes proteolytic cleavage by papain, resulting in a $45-\mathrm{kDa}$ fragment from the C-terminal of the heavy chain, called the $C$ frag. ment. The remainder of the molecule is termed the $\mathrm{B}$ fragment (Fig. 1B). Both fragments lack the toxicity of the intact toxin in vivo (Weller et al., 1986). Although tetanus toxin has no effect on intact chromaffin cells, Penner et al. (1986) have demonstrated that tetanus toxin and its B fragment, when introduced into chromaffin cells via patch pipette, were able to block $\mathrm{Ca}^{2+}$ dependent secretion, as measured by an increase in capacitance, whereas the $\mathrm{C}$ fragment was inactive. We have used digitonin-permeabilized chromaffin cells to confirm this result and to characterize the intracellular effects of tetanus toxin and its $\mathrm{B}$ and $\mathrm{C}$ fragments on $\mathrm{Ca}^{2+}$-dependent secretion (Bittner and Holz, 1988). Because the $\mathbf{B}$ fragment contains the entire light chain and part of the heavy chain, in this study we examined the effect of the isolated light chain on secretion. In addition, we also investigated the effects of monoclonal antibodies directed against different regions of the holotoxin molecule on its ability to inhibit secretion.

\section{MATERIALS AND METHODS}

Primary dissociated cells from bovine adrenal medulla were prepared and maintained as described previously (Bittner and Holz, 1988). After cells were labeled with $\left[{ }^{3} \mathrm{H}\right]$ norepinephrine, they were rinsed three times over a 40 -min period with physiological salt solution containing $145 \mathrm{~m} M \mathrm{NaCl}, 5.6 \mathrm{~m} M$ $\mathrm{KCl}, 2.2 \mathrm{~m} M \mathrm{CaCl}_{2}, 0.5 \mathrm{~m} M \mathrm{MgCl}_{2}, 5.6 \mathrm{~m} M$ glucose, 15 $\mathrm{m} M$ HEPES (pH 7.4), and $0.5 \mathrm{~m} M$ ascorbate. The potassium glutamate-, EGTA-, and piperazine- $N, N^{\prime}$-bis(2-ethanesulfonic acid) (PIPES)-containing solution (KGEP) that was used for secretion experiments with digitonin contained $139 \mathrm{~m} M$ po-

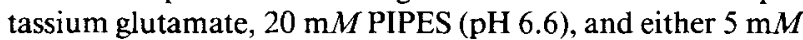
EGTA (without $\mathrm{Ca}^{2+}$ ) or $5 \mathrm{~m} M$ EGTA and $4.43 \mathrm{~m} M \mathrm{CaCl}_{2}$ to yield a buffered $\mathrm{Ca}^{2+}$ concentration of $10 \mu M$. Toxin or toxin fragments were diluted from a stock containing $0.5 \mathrm{M}$ $\mathrm{NaCl}$ and $0.1 M$ phosphate buffer, $\mathrm{pH} \mathrm{6.5}$. Control wells received an equal volume of $0.5 \mathrm{M} \mathrm{NaCl}$ and $0.1 \mathrm{M}$ phosphate buffer, $\mathrm{pH}$ 6.5. At the end of an experiment, the incubation solution was removed, and the cells were lysed with $1 \%$ Triton $\mathrm{X}-100$. The radioactivity released into the incubation solutions and the radioactivity remaining in the cells were deter-
Received January 10, 1989; accepted February 28, 1989.

Address correspondence and reprint requests to Dr. M. A. Bittner at M6322 Medical Science Building I, Department of Pharmacology, University of Michigan Medical School, Ann Arbor, MI 48109-0626, U.S.A.
Abbreviations used: kDa, kilodalton; KGEP, potassium glutamate-, EGTA-, and PIPES-containing solution; PIPES, piperazine- $N, N^{\prime}$ bis(2-ethanesulfonic acid). 
mined by liquid scintillation spectrometry. Experiments were performed at $25^{\circ} \mathrm{C}$.

Data are expressed as mean \pm SEM values unless otherwise indicated. The significance of differences between groups was determined by analysis of variance or by Student's $t$ test. Error bars smaller than symbols were omitted from figures.

Tetanus toxin light chain and monoclonal antibodies were prepared and characterized as described previously (Kenimer et al., 1983; Lin et al., 1985). Tetanus exotoxin (lot 606267) and tetanus toxin B (lot 605275) and C(lot 607243) fragments were purchased from Calbiochem (San Diego, CA, U.S.A.), digitonin from Fluka Chemical Corp. (Hauppage, NY, U.S.A.), and $l-\left[{ }^{3} \mathrm{H}\right]$ norepinephrine $(21.4 \mathrm{Ci} / \mathrm{mmol})$ from New England Nuclear (Boston, MA, U.S.A.). Other reagents were obtained from Sigma Chemical Co. (St. Louis, MO, U.S.A.).

\section{RESULTS AND DISCUSSION}

Tetanus toxin light chain inhibited $\mathrm{Ca}^{2+}$-dependent secretion from permeabilized chromaffin cells by $>80 \%$ (Fig. 2). When permeabilized chromaffin cells were preincubated with $50 \mu \mathrm{g} / \mathrm{ml}$ of tetanus toxin B fragment or $40 \mu \mathrm{g} / \mathrm{ml}$ of light chain for $6 \mathrm{~min}$, subsequent secretion stimulated by $\mathrm{Ca}^{2+}$ was inhibited by 56 and $87 \%$, respectively. Because the light chain is only onehalf the mass of the $B$ fragment, the light chain is at least as effective as the $B$ fragment at inhibiting secretion. Only a very small quantity $(<20 \mu \mathrm{g})$ of the light chain was available, so we were unable to establish a dose-effect curve for the inhibitory effects of the light chain. In fact, to reproduce this experiment, the incubation medium containing the light chain was removed from the cells, dialyzed overnight against KGEP buffer ( $\mathrm{pH}$ 6.6), reconstituted with $\mathrm{MgATP}, \mathrm{MgCl}_{2}$, and KGEP buffer, and used in a second experiment. In both experiments, the light chain was a potent inhibitor of secretion.

This result directly demonstrates that once the light chain of the toxin gains access to the secretory apparatus, the presence of all or part of the heavy chain is unnecessary for the inhibition to occur. In this respect, tetanus toxin follows the pattern of diphtheria toxin, in which the light chain is known to inhibit protein synthesis, and botulinum toxins A and B, whose isolated light chains also inhibit exocytosis in permeabilized chromaffin cells (Bittner et al., 1989).

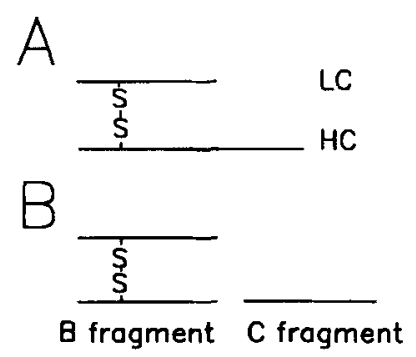

FIG. 1. Structure of dichain tetanus toxin before (A) and after (B) enzymatic cleavage by papain. LC, light chain; HC, heavy chain.

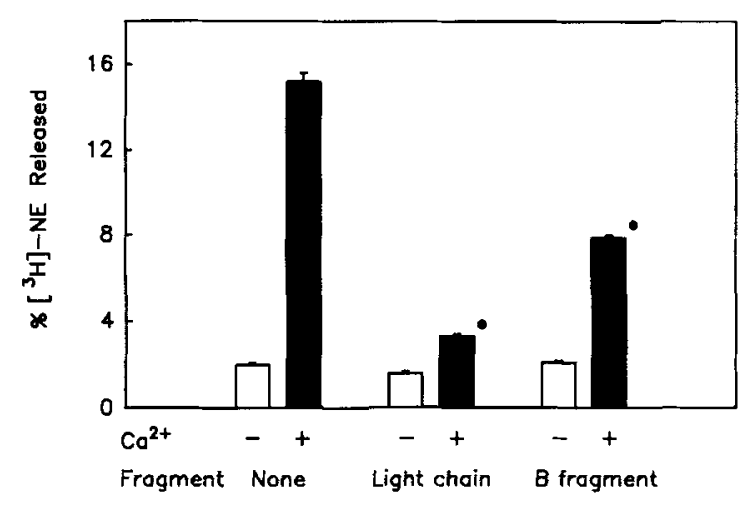

FIG. 2. Tetanus toxin light chain inhibits secretion from permeabilized chromaffin cells. Chromaffin cells were labeled for $2 \mathrm{~h}$ in culture medium containing $\left[{ }^{3} \mathrm{H}\right]$ norepinephrine $\left(\left[{ }^{3} \mathrm{H}\right] \mathrm{NE}\right)(2.5 \mu \mathrm{Cl} / \mathrm{ml})$ and $0.5 \mathrm{mM}$ ascorbate, rinsed in physiological saline containing $0.5 \mathrm{mM}$ ascorbate and $5.6 \mathrm{mM}$ glucose, and permeabilized for $4 \mathrm{~min}$ without $\mathrm{Ca}^{2+}$ in KGEP solution containing $1 \mathrm{mM} \mathrm{MgCl}$, $2 \mathrm{mM} \mathrm{MgATP}, 20$ $\mu M$ digitonin, and $0.5 \%$ bovine serum albumin. This solution was removed, and the cells were incubated for $6 \mathrm{~min}$ without digitonin or $\mathrm{Ca}^{2+}$ in KGEP with and without $40 \mu \mathrm{g} / \mathrm{ml}$ of tetanus toxin light chain or $50 \mu \mathrm{g} / \mathrm{ml}$ of tetanus toxin B fragment. This solution was removed, and the cells were stimulated to secrete with or without $10 \mu \mathrm{M} \mathrm{Ca}^{2+}$ in KGEP for $15 \mathrm{~min}$. The amount of $\left[{ }^{3} \mathrm{H}\right] \mathrm{NE}$ released into the incubation medium and that remaining in the cells were determined by liquid scintillation spectrometry. $\mathrm{Ca}^{2+}$-dependent secretion was the difference between secretion in the absence of $\mathrm{Ca}^{2+}$ (open columns) and total secretion in the presence of $10 \mu \mathrm{M}$ $\mathrm{Ca}^{2+}$ (solid columns). Data are mean \pm SEM (bars) values ( $n=3$ wells/group). An asterisk indicates $p<0.001$ compared with secretion in the presence of $\mathrm{Ca}^{2+}$ and in the absence of toxin.

To support further the conclusion that the light chain is responsible for the inhibition of exocytosis, we used monoclonal antibodies directed against various portions of the tetanus toxin molecule. These antibodies had been previously characterized (Kenimer et al., 1983) using the same preparation of light chain as that used in this study. When tetanus toxin was preincubated with ascites fluid containing antibodies to the light chain (antibody 21.83 .4 or 21.18 .1 ), the ability of the toxin to inhibit secretion was reduced or abolished (Table 1). ${ }^{1}$ Nonimmune ascites fluid (ascites) or antibodies that recognize only the $C$ fragment (18.1.7) or the heavy-chain portion of the B fragment $(21.76 .10)$ did not prevent the inhibition by tetanus toxin. This suggests that the blockade of the toxin effect by antibodies that recognize the light chain is due to a specific blockade of the active site on the molecule, rather than a nonspecific effect such as preventing the toxin-antibody complex from entering the cell.

\footnotetext{
${ }^{1}$ The temporal limitations of the assay dictated the use of rather high concentrations of tetanus toxin, to ensure that sufficient toxin rapidly entered the cells. To avoid possible interference by the ascites fluid on permeabilization with digitonin, cells were permeabilized before introduction of ascites-containing solutions. This protocol necessitated a short incubation with tetanus toxin. A relatively small inhibition of secretion resulted, because the effects of tetanus toxin increase with time (Bittner and Holz, 1988).
} 
TABLE 1. Effect of monoclonal antibodies on inhibition of secretion by tetanus toxin

\begin{tabular}{|c|c|c|c|c|}
\hline \multirow{2}{*}{$\begin{array}{l}\text { Monoclonal } \\
\text { antibody }\end{array}$} & \multicolumn{2}{|c|}{$\mathrm{Ca}^{2+}$-dependent secretion } & \multirow{2}{*}{$\begin{array}{c}\text { Inhibition } \\
(\%)\end{array}$} & \multirow[b]{2}{*}{ p } \\
\hline & Without toxin & With toxin & & \\
\hline None & $9.8 \pm 0.6$ & $6.8 \pm 0.2$ & 31 & $<0.01$ \\
\hline Ascites & $8.5 \pm 0.3$ & $5.9 \pm 0.3$ & 31 & $<0.001$ \\
\hline $\begin{array}{l}21.83 .4(\mathrm{LC}) \\
21.18 .1(\mathrm{LC})\end{array}$ & $\begin{array}{l}9.0 \pm 0.7 \\
8.0 \pm 0.2\end{array}$ & $\begin{array}{l}7.8 \pm 0.2 \\
7.5 \pm 0.9\end{array}$ & $\begin{array}{r}12 \\
6\end{array}$ & $\begin{array}{l}\text { NS } \\
\text { NS }\end{array}$ \\
\hline $\begin{array}{l}18.1 .7(\mathrm{HC}) \\
21.76 .10(\mathrm{HC})\end{array}$ & $\begin{array}{l}8.5 \pm 0.2 \\
8.7 \pm 0.2\end{array}$ & $\begin{array}{l}5.7 \pm 0.2 \\
6.0 \pm 0.6\end{array}$ & $\begin{array}{l}33 \\
31\end{array}$ & $\begin{array}{l}<0.001 \\
<0.01\end{array}$ \\
\hline
\end{tabular}

Monoclonal antibodies in ascites fluid were preincubated with and without tetanus toxin in buffer for $30 \mathrm{~min}$ at $19^{\circ} \mathrm{C}$ before dilution with KGEP and addition to the cells. The final dilution of each antibody stock was 12.5 -fold. Cultured chromaffin cells were labeled with $\left[{ }^{3} \mathrm{H}\right]$ norepinephrine, permeabilized in KGEP containing $1 \mathrm{~m} M$ $\mathrm{MgCl}_{2}, 2 \mathrm{mM} \mathrm{MgATP}, 20 \mu M$ digitonin, and $0.5 \%$ bovine serum albumin for $\mathbf{4} \mathrm{min}$, incubated for $6 \mathrm{~min}$ with and without monoclonal antibodies and with and without $30 \mu \mathrm{g} / \mathrm{ml}$ of tetanus toxin in KGEP without digitonin or bovine serum albumin, and then incubated with and without $\mathrm{Ca}^{2+}$ in KGEP with bovine serum albumin (without toxin or antibodies) for $18 \mathrm{~min}$. Finally, $\left[{ }^{3} \mathrm{H}\right]$ norepinephrine release was determined. $\mathrm{Ca}^{2+}$-dependent secretion was the difference between secretion in the absence of $\mathrm{Ca}^{2+}$ and total secretion in the presence of $10 \mu M$ free $\mathrm{Ca}^{2+}$. Data are mean \pm SEM values ( $\mathrm{n}=3$ wells/ group). LC, light chain; HC, heavy chain.

The antibodies we used had also been characterized for their ability to neutralize the lethal effects of tetanus when injected into mice (Kenimer et al., 1983). Both antibodies that reacted with the heavy-chain portion of the toxin (21.76.10 and 18.1.7) were very effective at neutralizing its lethal effects. Of the antibodies that recognize the light chain, antibody 21.83 .4 was moderately effective at neutralization, whereas the neutralization titer of antibody 21.18 .1 was below the limits of detection $(<0.001 \mathrm{U} / \mathrm{ml})$. Neutralization may be accomplished by inhibiting the binding and/or the in- ternalization of the toxin or, as Kenimer et al. (1983) suggest, by inhibiting some event that occurs subsequent to the initial toxin-receptor formation.

In summary, the experiments with the purified light chain of tetanus toxin and with monoclonal antibodies directed against various portions of the tetanus toxin indicate that the light chain is responsible for the intracellular blockade of exocytosis. This study did not address the question of intracellular processing of the holotoxin. Thus, it is unclear whether the intracellular, neurotoxic effects of tetanus toxin in vivo are mediated by the light chain as part of the dichain holotoxin or by light chain that may be separated from the heavy chain after internalization.

Acknowledgment: The work was supported by U.S. Public Health Service grant R01 DK27959. R. W. Holz is an Established Investigator of the American Heart Association.

\section{REFERENCES}

Bittner M. A. and Holz R. W. (1988) Effects of tetanus toxin on catecholamine release from intact and digitonin-permeabilized chromaffin cells. J. Neurochem. 51, 451-456.

Bittner M. A., DasGupta B. R., and Holz R. W. (1989) Isolated light chains of botulinum neurotoxins inhibit exocytosis: studies in digitonin-permeabilized chromaffin cells. J. Biol. Chem. (in press).

Kenimer J. G., Habig W. H., and Hardegree M. C. (1983) Monoclonal antibodies as probes of tetanus toxin structure and function. Infect. Immun. 42, 942-948.

Lin C. S., Habig W. H., and Hardegree M. C. (1985) Antibodies against the light chain of tetanus toxin in human sera. Infect. Immun. 49, 111-115.

Penner R., Neher E., and Dreyer F. (1986) Intracellularly injected tetanus toxin inhibits exocytosis in bovine adrenal chromaffin cells. Nature 324, 76-78.

Weller U., Taylor C. F., and Habermann E. (1986) Quantitative comparison between tetanus toxin, some fragments and toxoid for binding and axonal transport in the rat. Toxicon 24, 10551063. 